\title{
ПОЛІМОРФІЗМ ГЕНА РRО12ALA PРAR- 2 У ХВОРИХ НА НЕАЛКОГОЛЬНУ ЖИРОВУ ХВОРОБУ ПЕЧІНКИ, АРТЕРІАЛЬНУ ГІПЕРТЕНЗІЮ ТА ОЖИРІННЯ
}

\section{ВДНЗ «Буковинський державний медичний університет», м. Чернівці}

๑Ю. М. Яринич

PЕЗЮМЕ. На сьогодні $\epsilon$ багато суперечливих відомостей про роль поліморфізму генів сімейства $P P A R-\gamma 2$ у розвитку метаболічного синдрому, дисліпідемій, артеріальної гіпертензії (АГ) та ожиріння.

Мета - проаналізувати частоту алелів і генотипів Рго12Ala поліморфізму гена PPAR- 2 у структурі хворих на НАЖХП із есенціальною АГ, обтяженою абдомінальним ожирінням (АО).

Матеріал і методи. У 96 хворих на НАЖХП у поєднанні із есенціальною АГ ІІ стадії та АО 1-2 ступенів виконали дослідження Рго12Ala поліморфізму гена PPAR- 2 методом ПРЛ. Чоловіків було 41,67 \%, жінок- 58,33\%. Середній вік хворих становив $(53,70 \pm 5,34)$ років. Групу контролю склали 50 практично здорових осіб, зіставних за віком

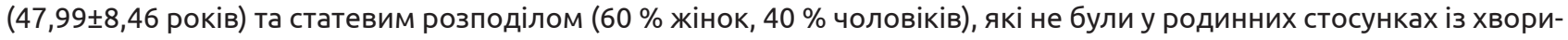
ми.

Результати. Серед обстежених стеатогепатит із мінімальною активністю мезенхімально-запального процесу реєстрували у 16,67 \% (16) хворих, у 83,33 \% (80) випадків виявили стеатогепатоз. 27,08 \% (26) осіб мали АО I ступеня, 58,33 \% (56) осіб - АО ІІ ступеня, 14,58 \% (14) пацієнтів - АО III ступеня.

Загалом, як серед осіб групи контролю, так і серед хворих, переважав Рго-алель у 6,14 і 3,85 раза ( $<<0,001)$ відповідно, без вірогідної різниці у частоті окремих генотипів. Однак у осіб групи контролю вірогідно частіше реєстрували дикий Рго-алель, рідше Аlа-алель, ніж у хворих на НАЖХП із есенціальною АГ, АО І ступеня на 16,77\% $\left(\chi^{2}=5,06, p=0,024\right)$. Частота алелів та генотипів гена PPAR- 2 (гs1801282) між хворими на стеатогепатит і стеатогепатоз вірогідно не відрізнялась. Однак відносна частота осіб із AlaAla- і ProAla-генотипами і, відповідно, із Ala-алелем була вірогідно більшою у хворих на стеатогепатит, ніж у контролі - на 30,25 \% $\left(\chi^{2}=4,99 ; p=0,025\right)$ і 17,25 \% $\left(\chi^{2}=4,85\right.$; $\mathrm{p}=0,028)$. Натомість, відносна частота осіб із РгоРго-генотипом та Рго-алелем, навпаки, була меншою, ніж у контролі, на 30,25\% (p=0,025) і 17,25\% ( $p=0,028)$. та AO.

Висновки. Ala-алель гена PPAR-y2 (Рго12Ala) асоціюється із більшою частотою стеатогепатиту у хворих на АГ

КлючОВІ СлОВА: неалкогольна жирова хвороба печінки; ген PPAR-ү2 (Рго12Ala), артеріальна гіпертензія, ожиріння.

Вступ. Неалкогольна жирова хвороба печінки (НАЖХП) - це спектр захворювань від простого стеатозу до клінічно значущих неалкогольного стеатогепатиту та цирозу печінки, для яких характерні процеси запалення і фіброзу. НАЖХП тісно пов'язана з ожирінням та інсулінорезистентністю [1].

Паралельно із збільшенням поширеності в популяції ожиріння та цукрового діабету [2] частота НАЖХП різко зросла. На сучасному етапі вважають, що НАЖХП $є$ найпоширенішою причиною захворювань печінки у Західній Європі [3-5]. При вивченні поширеності НАЖХП в країнах Європи та Північної Америки встановлено, що цей показник коливається від 20 до 30 \% у різник країнах [6, 7] та зростає до $90 \%$ за умови розвитку патологічного ожиріння [8].

За наявності НАЖХП ризик розвитку цукрового діабету 2 типу підвищується у 2 рази, а серцево-судинних захворювань - у 1,4-2 рази [9]. Крім того, серцево-судинні захворювання $\epsilon$ найчастішою причиною смерті серед пацієнтів із НАЖХП. Проаналізовано кількість випадків смерті пацієнтів від поєднаної патології серцево-судинної системи та НАЖХП, на яку припадає 25 \%, та поєднання серцево-судинної патології з іншими захворюваннями печінки - 13 \% [10].

Однак, оскільки тільки у деяких пацієнтів 3 НАЖХП розвиваються більш ускладнені форми неалкогольного стеатогепатиту, можна припустити, що прогресування захворювання має комплексну етіологію та залежить від взаємодії певних чинників і наявності генетичної схильності $[4,11]$.

На сьогодні $є$ багато суперечливих відомостей про роль поліморфізму генів сімейства $P P A R-\gamma 2$ у розвитку метаболічного синдрому, дисліпідемій, артеріальної гіпертензії (АГ), ожиріння тощо. Однак відомості щодо асоціації даного Рго12Ala поліморфізму гена $P P A R-\gamma 2$ із появою неалкогольної жирової хвороби печінки обмежені.

Метою нашого дослідження було проаналізувати частоту алелів і генотипів Pro12Ala поліморфізму гена $P P A R-\gamma 2$ у структурі хворих на НАЖХП із есенціальною АГ, обтяженою абдомінальним ожирінням (АО).

Матеріал і методи дослідження. У 96 хворих на НАЖХП у поєднанні із есенціальною АГ II стадії та AO 1-2 ступенів виконали дослідження Pго12Ala поліморфізму гена PPAR- 2 методом ПРЛ. Чоловіків було 41,67 \%, жінок - 58,33 \%. Се- 
Огляди літератури, оригінальні дослідження, погляд на проблему, ювілеї

редній вік хворих становив $(53,70 \pm 5,34)$ років. Групу контролю склали 50 практично здорових осіб, зіставних за віком $(47,99 \pm 8,46$ років) та статтю (60\% жінок, 40 \% чоловіків), які не були у родинних стосунках із хворими.

Результати й обговорення. Серед обстежених стеатогепатит із мінімальною активністю мезенхімально-запального процесу реєстрували у $16,67 \%$ (16) хворих, у 83,33 \% (80) випадків виявили стеатогепатоз. 27,08 \% (26) осіб мали АО І ступеня, 58,33 \% (56) осіб - АО ІІ ступеня, 14,58 \% (14) пацієнтів - АО ІІІ ступеня.

Розподіл генотипів гена PPAR- 2 (гs1801282) у обстежених відповідав популяційній рівновазі Hardy-Weinberg. Загалом, як серед осіб групи контролю, так і серед хворих переважав Ргоалель, у 6,14 і 3,85 рази ( $p<0,001)$ відповідно, без вірогідної різниці у частоті окремих генотипів. Однак у осіб групи контролю вірогідно частіше реєстрували дикий Рго-алель, рідше Аlа-алель,

\section{ЛІТЕРАТУРА}

1. Thorand B. Associations between leptin and leptin/adiponectin ratio and incident type 2 diabetes in middle-age men and women: results from the MONICA/ KORA Augsburg study 1984-2002 / B. Thorand, A. Zeirer, J. Baumertetal // Diabetic Medicine. - 2010. - Vol. 27. P. 1004-1011.

2. Vuppalanchi R. Nonalcoholic fatty liver disease and nonalcoholic steatohepatitis: selected practical issues in their evaluation and management / R. Vuppalanchi, N. Chalasani // Hepatology. - 2009. - Vol. 49. P. 306-317.

3. deAlwis N. M. Non-alcoholic fatty liver disease: the mist gradually clears / N. M. de Alwis, C. P. Day // J. Hepatol. - 2008. - Vol. 48 (Suppl. 1). - P. 104-112.

4. Petta S. Non-alcoholic fatty liver disease pathogenesis: the present and the future / S. Petta, C. Muratore, A. Craxi // Dig. Liver Dis. - 2009. - Vol. 41. - P. 615-625.

5. Dowman J. K. Pathogenesis of non-alcoholic fatty liver disease / J. K. Dowman, J. W. Tomlinson, P. N. Newsome // QJM. - 2010. - Vol. 103. - P. 71-83.

\section{REFERENCES}

1. Thorand, B., Zeirer, A., \& Baumertetal, J. (2010). Associations between leptin and leptin/adiponectin ratio and incident type 2 diabetes in middle-age men and women: results from the MONICA/KORA Augsburg study 1984-2002. Diabetic Medicine, 27, 1004-1011.

2. Vuppalanchi, R., \& Chalasani, N. (2009). Non-alcoholic fatty liver disease and nonalcoholic steatohepatitis: selected practical issues in their evaluation and management. Hepatology, 49, 306-317. ніж у хворих на НАЖХП із есенціальною АГ, АО І ступеня, на $16,77 \%\left(\chi^{2}=5,06, p=0,024\right)$. Частота

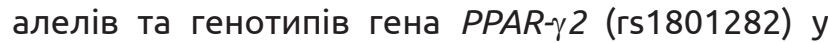
хворих на стеатогепатит і стеатогепатоз вірогідно не відрізнялась. Однак відносна частота осіб із AlaAla- i ProAla-генотипами i, відповідно, із Alaалелем була вірогідно більшою серед хворих на стеатогепатит, ніж у контролі - на 30,25 \% ( $\chi^{2}=4,99$; p=0,025) і $17,25 \%\left(\chi^{2}=4,85 ; p=0,028\right)$. Натомість, відносна частота осіб із РгоРго-генотипом та Ргоалелем, навпаки, була меншою, ніж у контролі, на $30,25 \%(p=0,025)$ i $17,25 \%(p=0,028)$.

Висновки. Ala-алель гена PPAR- 2 (Pro12Ala) асоціює із більшою частотою стеатогепатиту у хворих на АГ та АО.

Перспективи подальших досліджень. Планується подальше вивчення генетичного компонента для встановлення корелятивних зв'язків між НАЖХП, ожирінням та наявністю цукрового діабету.

6. Day C. P. From fat to inflammation / C. P. Day // Gastroenterology. - 2006. - Vol. 130. - P. 207-210

7. Prevalence of hepatic steatosis in an urban population in the United States: impact of ethnicity / J. D. Browning, L. S. Szczepaniak, R. Dobbins [et al.] // Hepatology. 2004. - Vol. 40. - P. 1387-1395.

8. Prevalence of and risk factors for nonalcoholic fatty liver disease: the Dionysos nutrition and liver study / G. Bedogni, L. Miglioli, F. Masutti [et al.] // Hepatology. 2005. - Vol. 42. - P. 44-52.

9. Machado M. Hepatic histology in obese patients undergoing bariatric surgery / M. Machado, P. MarquesVidal // J. Hepatol. - 2006. - Vol. 45. - P. 600-606.

10. Need for a three-focused approach to nonalcoholic fatty liver disease / G. Musso, R. Gambino, M. Cassader [et al.] // Hepatology - 2011. - Vol. 53 (5) - P.1773.

11. The natural history of nonalcoholic fatty liver disease: a population-based cohort study / L. A. Adams, J. F. Lymp, J. St. Sauver [et al.] // Gastroenterology. - 2005. Vol. 129(1) - P. 113-121.

3. de Alwis, N.M., \& Day, C.P. (2008). Non-alcoholic fatty liver disease: the mist gradually clears. J. Hepatol., 48 (1), 104-112.

4. Petta, S., Muratore, C., \& Craxi, A. (2009). Non-alcoholic fatty liver disease pathogenesis: the present and the future. Dig. Liver Dis., 41, 615-625.

5. Dowman, J.K., Tomlinson, J.W., \& Newsome, P.N. (2010). Pathogenesis of non-alcoholic fatty liver disease. QJM, 103, 71-83. 
Огляди літератури, оригінальні дослідження, погляд на проблему, ювілеї

6. Day, C.P. (2006). From fat to inflammation. Gastroenterology, 130, 207-210.

7. Browning, J.D., Szczepaniak, L.S., \& Dobbins, R. (2004). Prevalence of hepatic steatosis in an urban population in the United States: impact of ethnicity. Hepatology, 40, 1387-1395.

8. Bedogni, G., Miglioli, L., \& Masutti, F. (2005). Prevalence of and risk factors for nonalcoholic fatty liver disease: the Dionysos nutrition and liver study. Hepatology, $42,44-52$.
9. Machado, M., \& Marques-Vidal, P. (2006). Hepatic histology in obese patients undergoing bariatric surgery. J. Hepatol., 45, 600-606.

10. Musso, G., Gambino, R., \& Cassader, M. (2011). Need for a three-focused approach to nonalcoholic fatty liver disease. Hepatology, 53 (5), 1773.

11. Adams, L.A., Lymp, J.F., \& Sauver, J. St. (2005). The natural history of nonalcoholic fatty liver disease: a population-based cohort study. Gastroenterology, 129 (1), 113-121.

\title{
ПОЛИМОРФИЗМ ГЕНА РRO12ALA PPAR $\gamma 2$ У БОЛЬНЫХ НЕАЛКОГОЛЬНОЙ ЖИРОВОЙ БОЛЕЗНЬЮ ПЕЧЕНИ, АРТЕРИАЛЬНОЙ ГИПЕРТЕНЗИЕЙ И ОЖИРЕНИЕМ
}

ФЮ. Н. Яринич

\author{
ВГУз «Буковинский государственный медицинский университет», г. Черновцы
}

РЕЗЮмЕ. Сегодня существует много противоречивых сведений о роли полиморфизма генов семейства $P P A R-\gamma 2$ в развитии метаболического синдрома, дислипидемии, артериальной гипертензии (АГ) и ожирения.

Цель - проанализировать частоту аллелей и генотипов Рго12Ala полиморфизма гена PPAR- 2 в структуре больных НАЖХП с эссенциальной АГ, отягощенной абдоминальным ожирением (АО).

Материал и методы. У 96 больных НАЖХП в сочетании с эссенциальной АГ ІІ стадии и АО 1-2 степени выполнили исследования Pro12Ala полиморфизма гена PPAR- 2 методом ПЦР. Мужчин было 41,67 \%, женщин $58,33 \%$. Средний возраст больных составил $(53,70 \pm 5,34)$ лет. Группу контроля составили 50 практически здоровых

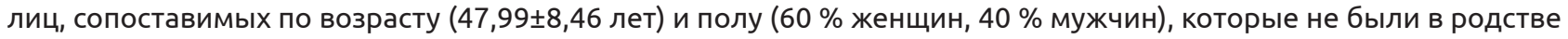
с больными.

Результаты. Среди обследованных стеатогепатит с минимальной активностью мезенхимально-воспалительного процесса регистрировали у 16,67 \% (16) больных, в 83,33 \% (80) случаев обнаружили стеатогепатоз. 27,08 \% (26) больных имели АО І степени, 58,33 \% (56) больных - АО II степени, 14,58 \% (14) пациетов - АО III степени.

В общем, как среди лиц группы контроля, так и среди больных преобладал Рго-аллель в 6,14 и 3,85 раза ( $<<0,001)$ соответственно, без достоверной разницы в частоте отдельных генотипов. Однако у лиц группы контроля достоверно чаще регистрировали дикий Рго-аллель, реже Alа-аллель, чем у больных НАЖХП с эссенциальной АГ, АО І степени на $16,77 \%\left(\chi^{2}=5,06, p=0,024\right)$. Частота аллелей и генотипов гена PPAR- 2 (гs1801282) между больными со стеатогепатитом и стеатогепатозом достоверно не отличалась. Однако относительная частота лиц c AlaAla- и ProAla-генотипами и, соответственно, с Ala-аллелем была достоверно большей у больных стеатогепатитом, чем в контроле - на 30,25 \% ( $\left.\chi^{2}=4,99 ; p=0,025\right)$ и 17,25 \% ( $\left.\chi^{2}=4,85 ; p=0,028\right)$. Зато относительная частота лиц с РгоРго-генотипом и Рго-геном, наоборот, была меньше, чем в контроле, на $30,25 \%$ ( $p=0,025)$ и 17,25 \% ( $p=0,028)$.

Выводы. Ala-аллель гена PPAR- 2 (Рго12Ala) ассоциирует с большей частотой стеатогепатита у больных АГ и АО.

КЛЮчЕВЫЕ СЛОВА: неалкогольная жировая болезнь печени; ген PPAR- 2 (Рго12Ala); артериальная гипертензия; ожирение.

\section{PRO12ALA PPAR- $\gamma 2$ GENE POLYMORPHISM IN PATIENTS WITH NON-ALCOHOLIC LIVER DISEASE, ARTERIAL HYPERTHERMIA AND EXPOSURE}

\author{
State Medical University "Bukovyna State Medical University", Chernivtsi
}

@Yu. N. Yarynych

SUMMARY. Today, there is a lot of controversial information on the role of PPAR- 2 gene polymorphisms in the development of metabolic syndrome, dyslipidemia, arterial hypertension (hypertension), and obesity.

The aim - to analyze the frequency of alleles and genotypes of the Pro12Ala polymorphism of the PPAR- $\gamma 2$ gene in the structure of patients with NAGHP with essential AG, burdened with abdominal obesity (AO).

Material and Methods. In 96 patients with NADH in combination with the essential AG II stage and AO 1-2 degrees performed the study of Pro12Ala polymorphism of the PPAR- 2 gene by PCR. Men were $41.67 \%$, women $-58.33 \%$. The average age of patients was $(53.70 \pm 5.34)$ years. The control group consisted of 50 practically healthy subjects, comparable in age ( $47.99 \pm 8.46$ years) and sex (60 \% women, $40 \%$ men) who were not related to the patients. 
Огляди літератури, оригінальні дослідження, погляд на проблему, ювілеї

Results. Among the examined steatohepatitis with the minimum activity of the mesenchymal-inflammatory process, $16.67 \%$ (16) patients were registered, and in $83.33 \%$ (80) of cases steatohepatosis was detected. $27.08 \%$ (26) persons had AO I degree, 58.33 \% (56) people - AO II degree, $14.58 \%$ (14) patients - AO III degree.

In general, both among the control group and among patients, the Pro-allele was dominated by 6.14 and 3.85 times $(p<0.001)$, respectively, without a significant difference in the frequency of individual genotypes. However, in the control group, the wild Pro-allele, less often Ala-allele, was significantly more frequent than in the patients with NAGHP with essential AG, AO I degree in $16.77 \%\left(\chi^{2}=5.06, \mathrm{p}=0.024\right)$. The frequency of alleles and genotypes of the PPAR- 2 gene (rs1801282) between patients with steatohepatitis and steatohepatose was not significantly different. However, the relative frequency of individuals with AlaAla- and ProAla-genotypes and, respectively, with the Ala-allele was significantly higher in patients with steatohepatitis than in the control - by $30.25 \%\left(\chi^{2}=4.99 ; p=0.025\right)$ and $17,25 \%\left(\chi^{2}=4.85 ; p=\right.$ 0.028). However, the relative frequency of persons with ProPro-genotype and Pro-genome per revolution was less than in control by $30.25 \%(p=0.025)$ and $17.25 \%(p=0.028)$.

Conclusions. The Ala-allele of the PPAR-y2 gene (Pro12Ala) is associated with a higher incidence of steatohepatitis in patients with hypertension and AO.

KEY WORDS: non-alcoholic fatty liver disease; gene PPAR- 2 (Pro12Ala); arterial hypertension; obesity.

Отримано 08.02.2018 